\title{
Evaluation of cytotoxicity and genotoxicity of Hancornia speciosa latex in Allium cepa root model
}

\author{
T. P. Ribeiro ${ }^{a}$, T. R. Sousa ${ }^{a}$, A. S. Arruda ${ }^{a}$, N. Peixoto ${ }^{a}$, P. J. Gonçalves ${ }^{b}$ and L. M. Almeida ${ }^{a *}$ \\ ${ }^{a}$ Laboratório de Biologia Molecular de Plantas, Universidade Estadual de Goiás - UEG, Unidade Universitária de Ipameri, \\ Rodovia GO 330, Km 241, Setor Universitário, CEP 75780-000, Ipameri, GO, Brazil \\ ${ }^{\text {b} L a b o r a t o ́ r i o ~ d e ~ F o t o f i ́ s i c a, ~ I n s t i t u t o ~ d e ~ F i ́ s i c a, ~ U n i v e r s i d a d e ~ F e d e r a l ~ d e ~ G o i a ́ s ~-~ U F G, ~ C a m p u s ~ S a m a m b a i a, ~}$ \\ CEP 74001-970, Goiânia, GO, Brazil \\ *e-mail: luciane.almeida@ueg.br
}

Received: September 25, 2014 - Accepted: December 15, 2014 - Distributed: February 29, 2016

(With 1 figure)

\begin{abstract}
The latex obtained from Hancornia speciosa Gomes (Mangabeira tree) is widely used in traditional medicine to treat a variety of diseases, including diarrhea, ulcer, gastritis, tuberculosis, acne and warts. In this study, the cytotoxicity and genotoxicity effects of $H$. speciosa latex on the root meristem cells of Allium cepa were examined. Onion bulbs were exposed to different concentrations of latex and then submitted to microscopic analysis using Giemsa stain. Water was used as a negative control and sodium azide as a positive control. The results showed that, under the testing conditions, the mitotic index (MI) of the onion roots submitted to latex treatment did not differ significantly from the negative control, which suggests that the latex is not cytotoxic. Low incidence of chromosome aberrations in the cells treated with $H$. speciosa latex was also observed, indicating that the latex does not have genotoxic effect either. The MI and the chromosome aberration frequency responded to the latex concentration, requiring more studies to evaluate the dosage effect on genotoxicity. The results indicate that in tested concentrations $H$. speciosa latex is probably not harmful to human health and may be potentially used in medicine.
\end{abstract}

Keywords: Cerrado, popular medicine, mutagenesis.

\section{Avaliação da citotoxicidade e genotoxicidade do látex de Hancornia speciosa usando o modelo da raiz de Allium cepa}

\section{Resumo}

O látex obtido de Hancornia speciosa é amplamente utilizado na medicina popular para tratar uma variedade de doenças, tais como: diarreia, úlcera, gastrite, tuberculose, acne e verrugas. Nesse estudo, foram avaliados os efeitos citotóxicos e genotóxicos do látex de $H$. speciosa sobre as células meristemáticas das raízes de Allium cepa. Os bulbos das cebolas foram expostos a diferentes concentrações de látex e depois submetidos à analise microscópica usando o corante Giemsa. A água foi usada como controle negativo e a ázida sódica como controle positivo. Os resultados mostraram que o índice mitótico (IM) das raízes de cebola submetidas ao tratamento com látex, nas condições testadas, não diferiram significativamente do controle negativo, e sugerem que o látex não é citotóxico. Também foi observada uma baixa incidência de aberrações cromossômicas nas células tratadas com látex de $H$. speciosa, o que sugere que o látex também não possui efeito genotóxico. O IM e a frequência de aberrações cromossômicas foram dependentes da concentração de látex. Outros estudos devem ser realizados para avaliar o efeito da dose na genotoxidade. Os resultados indicam que o látex de mangabeira, nas concentrações testadas, provavelmente não é danoso para saúde humana e pode ter potencial para ser usado na medicina.

Palavras-chave: Cerrado, medicina popular, mutagênese.

\section{Introduction}

The World Health Organization (WHO) has estimated that $80 \%$ of the world population relies solely or largely on traditional medicines for health care (Bannerman, 1982), and there is speculation that more than two billion people may heavily resort to medicinal plants (Smith-Hall et al.,
2012). Despite the therapeutic advantages of medicinal plants, their potential toxicity has not been recognized by the general public or by professional groups of traditional medicine (Soetan and Aiyelaagbe, 2009), and many plant species commonly considered medicinal can contain 
potentially dangerous substances (Rodrigues et al., 2011). Recent research studies conducted in vitro and in vivo assay have revealed that many plants used as food or in traditional medicine have cytotoxic and genotoxic effects (Sehgal et al., 2006; Dalla Nora et al., 2010; Luz et al., 2012; Ping et al., 2012). Therefore, evaluating the toxicological effects of any herbal extract intended to be used in humans is of utmost importance.

One way to evaluate the toxicity of natural extracts of natural extracts of plants and/or medicinal plants, is the Allium cepa assay. This in vitro test is very useful as a first-tier analysis of cytotoxicity and genotoxicity, because of the simplicity, low relative cost, versatility and minimum laboratory facilities required for its performance (Khora et al., 1997). Moreover, the results obtained using the $A$. cepa root model show a high degree of conformity with the results obtained from mammalian assays (Luz et al., 2012).

Hancornia speciosa belongs in the Apocynaceae family and is commonly known as mangabeira. The latex from this species is widely used in traditional medicine to treat a variety of diseases, including diarrhea, ulcer, gastritis, tuberculosis, acne and warts (Pott and Pott, 1994; Ferreira et al., 2007). Moraes et al. (2008) demonstrated scientifically that this latex has gastro protective and healing activities in mice. More recently, its angiogenic properties were demonstrated using the chicken chorioallantoic membrane (CAM) assay model (Almeida et al., 2014). The objective of this study was to evaluate the cytotoxicity and genotoxicity potential of $H$. speciosa latex through in vitro genotoxicity bioassay on mitotic cells of A. cepa root tips.

\section{Material and Methods}

\subsection{Latex extraction}

The latex of $H$. speciosa was collected from Goiás State University tree collection, in the city of Ipameri, (Goiás State, Brazil). A voucher specimen was deposited at the University Herbarium (Goiás State University, Anápolis, Goiás, Brazil); the exsiccate was given the number 4875 . The latex was collected into a sterile container through cuts made into the tree trunk. The cuts were made in the bark with a knife and had approximately $10-\mathrm{cm}$ length and $0.5-\mathrm{cm}$ depth. The milky sap was submitted to different methodologies to prevent coagulation. Distilled water was added to latex at 1,5 , and $10 \%$ final concentrations.

\subsection{Allium cepa assay}

\subsubsection{Pre-treatment}

The $A$. сеpa bulbs were grown in tap water at room temperature for 2-3 days. When the roots were $2-4 \mathrm{~cm}$ in length, the bulbs were treated with different concentrations of mangabeira latex $(1,5$, and 10\%). Another set of plants was placed in azide sodium (2M) as a positive control, while for negative control, a set of $A$. cepa was grown in water. The solutions were changed daily, and after 48 hours the root tips from each bulb were harvested and fixed in Carnoy's fixative solution (1:3 acetic acid: alcohol) for 24 hours. Then, they were taken to plate preparation or stored in $70 \%$ alcohol.

\subsubsection{Slides preparation}

After pre-treatment, the root tips were rinsed a few times with distilled water. They were hydrolyzed with $5 \mathrm{M} \mathrm{HCl}$ solution at room temperature for $20 \mathrm{~min}$. After hydrolysis, the roots were dissected in acetic acid (45\%) and squashed with cover slip. The cover slips were removed after freezing in liquid nitrogen and stained with Giemsa (5\%) for 5-10 $\mathrm{min}$.

\subsubsection{Slides analysis}

The slides were evaluated using an Optical Microscope LEICA with 40 or 100 times magnification. In total 1,000 cells were analyzed per bulb, in 5 bulbs per treatment. The cytotoxic potential was calculated through observation of the mitotic index (MI). The MI was calculated for each treatment using the number of dividing cells / total number of cells (Seth et al. 2008). The genotoxic potential was estimated by the frequency of anomalies in the mitotic cycle (AMC) and the incidence of micronuclei (M).

\subsubsection{Statistical analysis}

The groups were divided into five treatments, each containing five replications, and the values were measured through variance analysis (ANOVA) and compared through Tukey test (SISVAR, 2010). P values of less than 0.05 $(\mathrm{P}<0.05)$ were considered as indicative of significance.

\section{Results}

Table 1 shows the effect of different concentrations of $H$. speciosa latex on root tips of $A$. cepa. To evaluate the cytotoxicity the mitotic index (MI) was considered, and

Table 1. Cytogenetic analysis of $A$. cepa root tips exposed to different concentration of $H$. speciosa latex.

\begin{tabular}{|c|c|c|c|c|c|c|}
\hline \multirow[b]{2}{*}{ Treatments } & \multirow[b]{2}{*}{$\begin{array}{l}\text { Total number } \\
\text { of cells }\end{array}$} & \multirow[b]{2}{*}{$\begin{array}{c}\text { Interphase } \\
\text { cells }\end{array}$} & \multirow[b]{2}{*}{$\begin{array}{l}\text { Division } \\
\text { cells }\end{array}$} & \multirow{2}{*}{$\begin{array}{l}\text { Cytotoxicity } \\
\text { Mitotic index } \\
(\%)\end{array}$} & \multicolumn{2}{|c|}{ Genotoxicity } \\
\hline & & & & & $\begin{array}{c}\text { Frequency of } \\
\text { Chromosome } \\
\text { Aberrations } \\
(\text { CA \%) }\end{array}$ & $\begin{array}{l}\text { Frequency of } \\
\text { Micronucleus } \\
\text { (M \%) }\end{array}$ \\
\hline Latex $1 \%$ & 5.033 & 4.015 & 1.018 & $20.2 \mathrm{~A}$ & $0.01 \mathrm{~A}$ & $0 \mathrm{~A}$ \\
\hline Latex 5\% & 5.027 & 3.678 & 1.349 & $26.8 \mathrm{~A}$ & $0.15 \mathrm{~A}$ & $0.01 \mathrm{~A}$ \\
\hline Latex $10 \%$ & 5.024 & 3.503 & 1.521 & $30.2 \mathrm{~A}$ & $0.47 \mathrm{~A}$ & $0 \mathrm{~A}$ \\
\hline Water & 5.060 & 3.735 & 1.325 & $26.1 \mathrm{~A}$ & $0 \mathrm{~A}$ & $0.05 \mathrm{~A}$ \\
\hline Sodium azide & 5.110 & 4.455 & 655 & $12.8 * \mathrm{~B}$ & $5.6^{*} \mathrm{~B}$ & $1.6^{*} \mathrm{~B}$ \\
\hline
\end{tabular}

Same letters represent no significant difference using Tukey test. *p<0.05 
to evaluate the genotoxicity the presence of micronucleus (M) and chromosome aberrations (CA) was recorded.

The results showed that the MI for $H$. speciosa latex does not differ significantly from the negative control, but it is significantly different from the positive control $(\mathrm{p}<0.05)$. This indicates that $H$. speciosa latex does not have a cytotoxic effect on $A$. cepa cells and the sodium azide has inhibitory and cytotoxic effect on the mitotic index (Khan et al., 2009). The MI increased progressively according to the increase in latex concentration (Table 1).

Chromosome aberrations were observed in very low frequency in all stages of mitosis. Table 1 shows the frequency of chromosome aberration in each treatment, and Figure 1 shows the types and frequency of each abnormality. To evaluate chromosome abnormalities through $A$. cepa test, several types of chromosome aberrations were considered. Chromosome stickiness means loss of normal appearance, and it presents sticky surface, causing chromosome agglomeration. Disturbance during metaphase and anaphase arises because of the effect of the treatment on the spindle, which leads to failure of the spindle mechanism. The chromosome bridge rises when the chromosome fails to separate due to chromosome stickiness. Micronuclei often result from acentric or lagging chromosome fragments that fail to incorporate into daughter cell nuclei during telophase. Chromosome bridges and lagging chromosome were the most common aberrations observed with latex treatment. In the positive control sample, the number of chromosome aberrations was significantly higher than with the latex treatment.

\section{Discussion}

Although an expressive number of medicinal plant species from the Brazilian Cerrado are known and used in popular medicine, detailed studies of their pharmacological and biological activity are still needed. In the case of $H$. speciosa, some scientific studies have showed the pharmacological potential of different parts of this plant. The extract obtained from the leaves has a hypotensive effect (Ferreira et al., 2007; Silva et al., 2011), the bark has anti-bactericidal activity (Moraes et al., 2008), and the latex has anti-inflammatory (Marinho et al., 2011) and angiogenic activities (Almeida et al., 2014). All these studies have been important to validating popular use of the mangabeira in diverse health practices.

Despite the pharmacological potential, the latex needs to be evaluated for biocompatibility in living tissues before its use. Biocompatibility has become the main requirement for medical application of materials and devices. The determination of cytotoxicity and genotoxicity is part of the initial evaluation process established by ISO standards 10993-3 (ISO, 1992a) and 10993-5 (ISO, 1992b). This is why H. speciosa latex was evaluated through the Allium cepa assay.

The Allium cepa assay has been widely used for evaluation of cytotoxic and genotoxic activity of various compounds (Del Campo et al., 2005; Liu et al., 2009; Frescura et al., 2013). Also, it has been validated as an international collaborative study under the United Nations Environmental Program (UNEP), World Health Organization (WHO) and US Environmental Protection Agency (USEPA), and as an efficient test for genetic monitoring. In the present

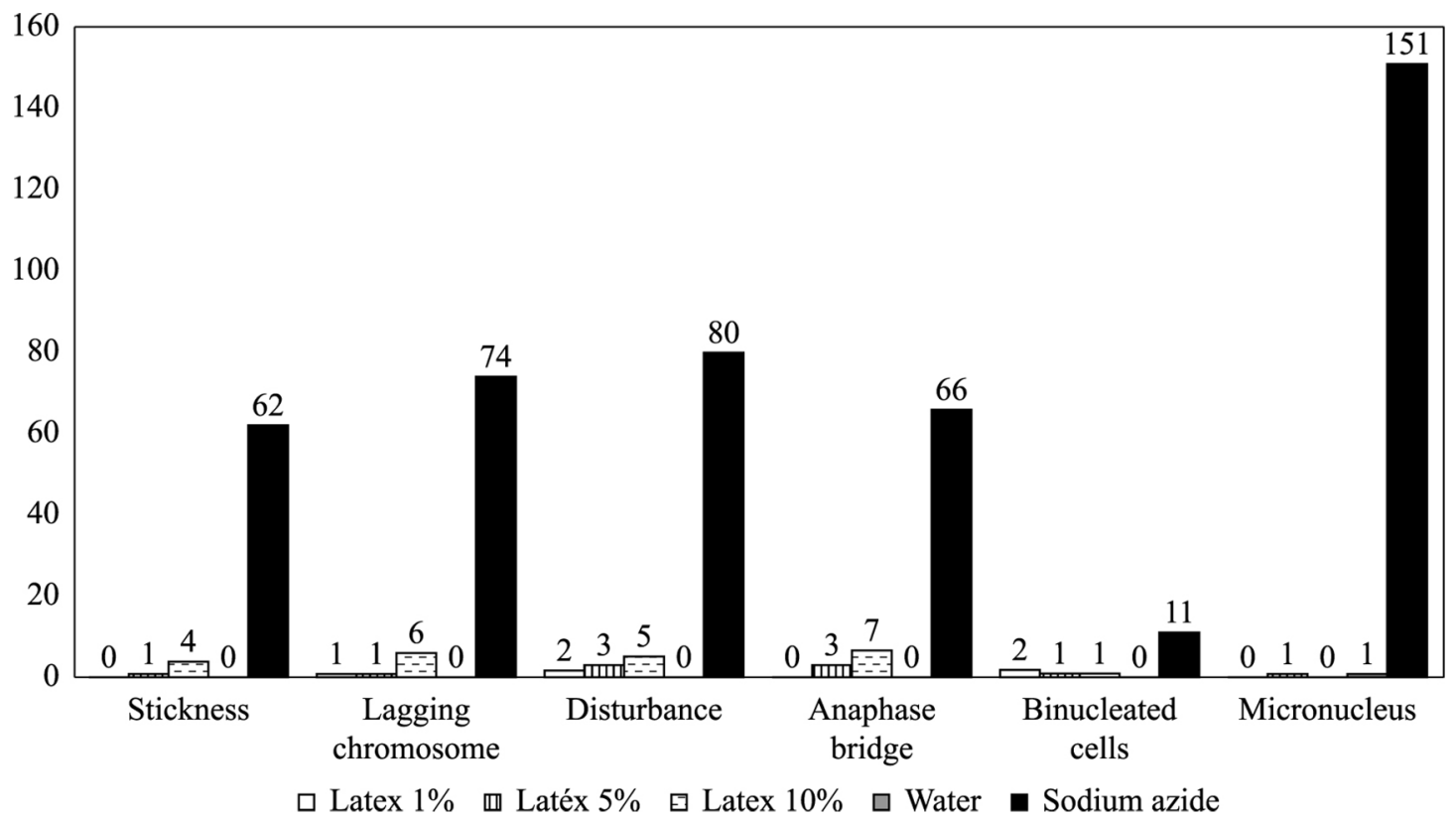

Figure 1. Occurrence of chromosome aberrations on root tip cells of $A$. cepa after treatment with different concentrations of $H$. speciosa latex. 
study the cytotoxic and genotoxic effects of $H$. speciosa latex were tested in A. cepa root tip meristem model and compared to a mutagenic drug (sodium azide).

The mitotic index (MI), characterized by the total number of cells in the cell cycle, has been a parameter to assess the cytotoxicity of several agents. The cytotoxicity level of an agent can be determined by an increase or decrease in the MI. MIs significantly lower than the negative control can indicate alterations deriving from the chemical action in the growth and development of the exposed organism. On the other hand, MIs higher than the negative control result from an increase in cell division, which can be harmful to the cells and lead to disorderly cell proliferation and even to the formation of tumor tissues (Leme and Marin-Morales, 2009). The increase in the mitotic index may result from shortening in the duration of the mitotic cycle, which allows interphase cells to enter the subsequent division stage (Al-Ahmadi, 2013).

In the present study no significant difference was observed between the latex treatment and the negative control. However, an increase could be observed in the MI and in the frequency of chromosome abnormality values with the increase in the latex concentration. Therefore, more studies are required to evaluate the appropriate dosage of this natural component during treatment. The cytotoxic and genotoxic results obtained in the present study are in agreement with Almeida et al. (2014), who tested the $H$. speciosa latex cytotoxicity and genotoxicity in mice fibroblast culture cells using the red neutral test and comet assay; these authors concluded that the $H$. speciosa latex (diluted 1:1 in water) does not present toxicity in vitro. In the same study, the authors evaluated the angiogenic potential of $H$. speciosa latex and observed an increase in the vascularization of chorioallantoic membrane (CAM) eggs, which suggested an angiogenic effect (Almeida et al., 2014). Maybe the increase in MI observed in this study can be associated to this angiogenic potential, since the angiogenesis process is characterized by cell proliferation.

In another study, Marinho et al. (2011) evaluated the $H$. speciosa toxicity in mice after oral latex administration analyzing the following parameters: convulsion, hyperactivity, seduction, grooming, loss of righting reflex, increase and decrease in respiration, and food and water intake. The results showed that $H$. speciosa latex does not have any toxic effect in mice. This work corroborates our analysis, suggesting that $H$. speciosa latex is not harmful to human health and could potentially be used in medicine.

\section{Conclusion}

The present study showed that $H$. speciosa latex does not present chromotoxic and mitodepressive effects on meristematic cells of $A$. cepa for the tested concentrations.

\section{Acknowledgements}

The authors wish to thank the Brazilian funding agencies $\mathrm{MCT} / \mathrm{CNPq}$, FNDCT, CAPES, FINEP and FAPEG, and also Goiás State University.

\section{References}

AL-AHMADI, M., 2013. Effects of organic insecticides, Kingbo and Azdar $10 \mathrm{EC}$, on mitotic chromosome in root tip cells of Allium cepa. International Journal of Genetics and Molecular Biology, vol. 5, no. 5, pp. 64-70. http://dx.doi.org/10.5897/ IJGMB2013.0074.

ALMEIDA, L.M., FLORIANO, J.F., RIBEIRO, T.P., MAGNO, L.N., MOTA, L.S.L.S., PEIXOTO, N., MRUÉ, F., MELO-REIS, P., LINO JUNIOR, R.S., GRAEFF, C.F.O. and GONÇALVES, P.J., 2014. Hancornia speciosa latex for biomedical applications: physical and chemical properties, biocompatibility assessment and angiogenic activity. Journal of Materials Science. Materials in Medicine, vol. 25, no. 9, pp. 2153-2162. http://dx.doi.org/10.1007/ s10856-014-5255-8. PMid:24973907.

BANNERMAN, R.H., 1982. Traditional medicine in modern health care. World Health Forum, vol. 3, pp. 8-13.

DALLA NORA, G., PASTORI, T., LAUGHINGHOUSE FOURTH, H.D., CANTO-DOROW, S.T. and TEDESCO, S.B., 2010. Antiproliferative and genotoxic effects of Mikania glomerata (Asteraceae). Biocell, vol. 34, no. 3, pp. 95-101. PMid:21443139.

DEL CAMPO, D.A., BRACHO, M., MARCANO, L., GUINEZ, J. and DE LA TORRE, C., 2005. DNA injury induced by 5 -aminouracil and caffeine in G2 checkpoints path of higher plant cells. Biocell, vol. 29 , no. 2 , pp. 169-176. PMid:16187495.

FERREIRA, H.C., SERRA, C.P., LEMOS, V.S., BRAGA, F.C. and CORTES, S.F., 2007. Nitric oxide-dependent vasodilatation by ethanolic extract of Hancornia speciosa via phosphatidylinositol 3-kinase. Journal of Ethnopharmacology, vol. 109, no. 1, pp. 161-164. http://dx.doi.org/10.1016/j.jep.2006.06.009. PMid:16890389.

FRESCURA, V.D., KHUN, A.W., LAUGHINGHOUSE FOURTH, H.D., PARANHOS, J.T. and TEDESCO, S.B., 2013. Post-treatment with plant extracts used in Brazilian folk medicine caused a partial reversal of the antiproliferative effect of glyohosate in the Allium cepa test. Biocell, vol. 37, no. 2, pp. 23-28. PMid:24392578.

INTERNATIONAL ORGANIZATION FOR STANDARDIZATION - ISO, 1992a. ISO 10.993-3: international standard: biological evaluation of medical devices - part 3. Tests for citotoxicity: In vitro methods ISO 10993-3. Geneva: ISO.

INTERNATIONAL ORGANIZATION FOR STANDARDIZATION - ISO, 1992b. ISO 10.993-5: international standard: Biological evaluation of medical devices - part 5. Tests for citotoxicity: In vitro methods ISO 10993-5. Geneva: ISO.

KHAN, S., AL-QURAINY, F. and ANWAR, F., 2009. Sodium azide: chemical mutagen for enhancement of agronomic traits of crop plants. Environment We International Journal Science Technology, vol. 4, pp. 1-21.

KHORA, S.S., PANDA, K.K. and PANDA, B.B., 1997. Genotoxicity of tetrodotoxin from puffer fish tested in root meristem cells of Allium cepa. Mutagenesis, vol. 12, no. 4, pp. 265-269. http:// dx.doi.org/10.1093/mutage/12.4.265. PMid:9237772.

LEME, D.M. and MARIN-MORALES, M.A., 2009. Allium cepa test in enverionmental monitoring: a review on its application. Mutation Research, vol. 682, no. 1, pp. 71-81. http://dx.doi. org/10.1016/j.mrrev.2009.06.002. PMid:19577002.

LIU, D., JIANG, W., MENG, Q., ZOU, J., GU, J. and ZENG, M., 2009. Cytogenetical and ultrastructural effects of copper on root meristem cells of Allium sativum L. Biocell, vol. 33, no. 1, pp. 25-32. PMid:19499883. 
LUZ, A.C., PRETTI, I.R., DUTRA, J.V.C. and BATITUCCI, M.C.P., 2012. Avaliação do potencial citotóxico e genotóxico de Plantago major L em sistemas teste in vivo. Revista Brasileira de Plantas Medicinais, vol. 14, no. 4, pp. 635-642. http://dx.doi. org/10.1590/S1516-05722012000400010.

MARINHO, D.G., ALVIANO, D.S., MATHEUS, M.E., ALVIANO, C.S. and FERNANDES, P.D., 2011. The latex obtained from Hancornia speciosa Gomes possesses anti-inflammatory activity. Journal of Ethnopharmacology, vol. 135, no. 2, pp. 530-537. http://dx.doi.org/10.1016/j.jep.2011.03.059. PMid:21463669.

MORAES, T.M., RODRIGUES, C.M., KUSHIMA, H., BAUAB, T.M., VIlleGAS, W., PELlizZON, C.H., BRITO, A. and HIRUMA-LIMA, C.A., 2008. Hancornia speciosa: Indications of gastroprotective, healing and anti-Heliobacter pilori actions. Journal of Ethnopharmacology, vol. 120, no. 2, pp. 161-168. http://dx.doi.org/10.1016/j.jep.2008.08.001. PMid:18761076.

PING, K.Y., DARAH, I., YUSUF, U.K., YENG, C. and SASIDHARAN, S., 2012. Genotoxicity of Euphorbia hirta: An Allium cepa asay. Molecules (Basel, Switzerland), vol. 17, no. 7, pp. 7782-7791. http://dx.doi.org/10.3390/molecules 17077782. PMid:22735780.

POTT, A. and POTT, V.J., 1994, Plantas do pantanal. Planaltina: EMBRAPA. 320 p.

RODRIGUES, H.G., MEIRELES, C.G., LIMA, J.T.S., TOLEDO, G.P., CARDOSO, J.L. and GOMES, S.L., 2011. Efeito embriotóxico, teratogênico e abortivo de plantas medicinais. Revista Brasileira de Plantas Medicinais, vol. 13, no. 3, pp. 359-366. http://dx.doi. org/10.1590/S1516-05722011000300016.

SEHGAL, R., ROY, S. and KUMAR, V.L., 2006. Evaluation of cytotoxic potential of latex of Calotropis procera and Podophyllotoxin in Allium cepa. Biocell, vol. 30, no. 1, pp. 9-13. PMid:16845823.

SETH, C.S., MISRA, V., CHAUHAN, L.K. and SINGH, R.R., 2008. Genotoxicity of cadmium on root meristem cells of Allium cepa: cytogenetic and comet assay approach. Ecotoxicology and Environmental Safety, vol. 71, no. 3, pp. 711-716. http://dx.doi. org/10.1016/j.ecoenv.2008.02.003. PMid:18358534.

SILVA, C.G., BRAGA, F.C., LIMA, M.P., PESQUERO, J.L., LEMOS, V.S. and CORTES, S.F., 2011. Hancornia speciosa Gomes induces hypotensive effect through inhibition of ACE and increase on NO. Journal of Ethnopharmacology, vol. 137, no. 1, pp. 709-711. http://dx.doi.org/10.1016/j.jep.2011.06.031. PMid:21756990.

SISVAR, 2010. Sisvar for Windows v. 5.3: computer program manual. Tulsa: StatSoft Inc.

SMITH-HALL, C., LARSEN, H.O. and POULIOT, M., 2012. People, plants and health: a conceptual framework for plant consumption. Journal of Ethnobiology and Ethnomedicine, vol. 8, no. 1, pp. 43. http://dx.doi.org/10.1186/1746-4269-8-43. PMid:23148504.

SOETAN, K.O. and AIYELAAGBE, O.O., 2009. The need for bioactivity-safety evaluation and conservation of medicinal plants. A review. Journal Medicinal Plants Research, vol. 3, pp. 324-328. 